\title{
The Relationship between University Innovation Ability and National Economic Growth based on Multinational Empirical Analysis
}

\author{
Achmad Alamsyah ${ }^{1}$ and Hendry Ratna ${ }^{2}$ \\ ${ }^{1,2}$ Universitas Muhammadiyah, Yogyakarta Yogyakarta, Indonesia \\ ${ }^{1}$ Achmad.alamsyah@mail.umy.ac.id, ${ }^{2}$ Hendry.ratna@mail.umy.ac.id
}

\begin{abstract}
This article discusses the important issue of university innovation ability and national economic growth through empirical methods. This article examines the relationship between university innovation ability and unit labor output from three aspects: university $R \& D$ funding input, university $R \& D$ personnel density, and government financial support for higher education. The research results show that: the enhancement of a university's innovation ability is conducive to the increase of unit labor output and is conducive to longterm economic growth. The quantile coefficient of university $R \& D$ expenditure first rose and then fell; the contribution coefficient of $R \& D$ personnel density to the increase in unit labor output continued to increase. There is a U-shaped relationship between the degree of government financial support for higher education and economic growth. On the one hand, enhancing the sources of funding for running schools through multiple channels will help colleges and universities to form a more effective interaction mechanism with society, and enhance the innovation vitality and motivation of their universities. On the other hand, due to the high-risk, unpredictable and long-term nature of innovation activities, the innovation activities implemented by universities have higher sunk costs than enterprises. Both scientific research and personnel training require continuous high investment.
\end{abstract}

Keywords: University innovation ability, National economic growth, Financial support, $R \& D$ funding

\section{Introduction}

As an important part of the national innovation system, universities have various functions such as conducting basic research, transforming scientific research results, training innovative talents, and inheriting innovative culture. In recent years, the world's major scientific and technological powers such as the United States, the European Union, and South Korea have issued or funded a series of plans and projects, investing large teams and special funds to enhance the innovation capabilities and international competitiveness of their universities, to give full play to the university's role in society. In 2012, the National Research Council of the National Academy of Sciences released a report titled "Research ties and the Future of America: Ten Breakthrough Actions Vital to Our Nation's Prosperity and Security", proposing that within the larger framework of innovation and R\&D strategies, The federal

Article history:

Received (August 5, 2019), Review Result (September 15, 2019), Accepted (November 25, 2019) 
government should adopt stable and effective policies, practices, and funding for university R\&D activities and graduate education for cultivating innovative talents, which embodies this policy orientation of developed countries.

Although current scholars generally agree that universities are indispensable in the national innovation system, empirical research on the specific contribution of university innovation to economic growth is not abundant. How to learn from international experience, take the promotion of innovative development as the guide, and accurately understand and grasp the different needs of different economic development stages for the university's innovation ability has important practical significance.

The significance of this article is that for a long time, there have been two different philosophical propositions regarding the innovative role of universities in academia: one view is that universities, as a palace for preserving and developing advanced knowledge, should stay away from commercialization and industrialization, and demonstrate their pure academic value and Eternity. Another view emphasizes the practical value of university knowledge and actively expands its function of serving social and economic development. Although the "Wisconsin Thought" of the early 20th century succeeded in advocating the social service functions of universities, the dispute between the two views has not been resolved. This article does not comment on this controversy, but the conclusion of this article may deepen the understanding of this issue in the chemical community.

\section{Basic theory}

\subsection{Relevant research on university innovation ability}

The discussion on university innovation capabilities mostly comes from various innovation theories, such as national innovation system theory [1][2], triple helix theory [3], open innovation theory [4], cross-organizational cooperation theory [5], etc. In recent years, scholars have carried out many useful explorations on the composition of university innovation capabilities, the status quo of university innovation capabilities in various countries and regions, and the evaluation of university innovation capabilities and their influencing factors. In the existing literature, the production and flow of knowledge, the cooperative relationship between universities and industry, and the cultivation of innovative talents have gradually become relatively independent research fields, and there have been many theoretical and empirical studies. For example, in terms of knowledge production and scientific research and innovation, Gibbons (M. Gibbons) and others proposed that under the knowledge economy, university knowledge production is shifting from a traditional discipline-oriented model to a problem-oriented and application-oriented approach, with emphasis on interdisciplinary and Knowledge production II model of cross-border cooperation [6]. From the perspective of university-industry cooperation, there is a huge amount of research on university innovation capabilities, and most of them are theoretically discussed. The content involves the basic model of industry-university-research cooperation, interest mechanisms, and existing problems [7]. In addition, innovative talents are an important component of the university's innovative capabilities. Scholars have reached a consensus on this point; however, due to the difficulty of measuring individual creativity accurately and the difficulty in obtaining data, related research is still in its infancy. In recent years, scholars have used the theories and measurement methods in psychology to make useful attempts from the perspectives of creative thinking and creative personality. 
Regarding the evaluation method of university innovation ability, although scholars choose different specific indicators, they mainly focus on the four dimensions of university innovation management system, university innovation investment, university innovation activities, and university innovation achievements. In terms of methods, both quantitative and qualitative researches are available, but the quantitative evaluation is largely limited by the statistical calibre and availability of data. Currently, the data available for research on university innovation is very limited. The statistical survey of the Organization for Economic Cooperation and Development (OECD) is the representative. Core evaluation indicators include university $R \& D$ funding and $R \& D$ human resources. In addition, scholars also actively explored the influencing factors of university innovation capabilities. For example, through a comparative analysis of European and American universities, some scholars discussed the institutional factors affecting university innovation capabilities, including the institutional arrangement of combining teaching and scientific research, the autonomy and competitive structure of universities, and the educational philosophy of transforming university scientific and technological achievements.

\subsection{The impact of university innovation ability on economic growth}

As mentioned above, the evaluation dimensions of university innovation capabilities are diverse, but due to the research and development funding of universities (also known as "university R\&D funding" or "university R\&D funding"

Furthermore, scholars have discovered that the impact of university innovation capabilities on economic growth has a relatively obvious spatial spill over effect, and there is an imbalance between regions. Research by scholars such as D. Woodward has shown that the spatial spill over effect of university innovation can spread to a range of 145 miles around [9].

To sum up, the correlation between university innovation ability and economic growth is becoming an important topic of concern to scholars at home and abroad, but the amount of literature is not abundant, and there is room for improvement in the following aspects: First, empirical research The selection of indicators is relatively single. Although funding investment is indispensable for enhancing the innovation ability of universities, it is not the only one. Personnel investment, the degree of government efforts in higher education, and the institutional environment of various countries are also important factors in improving the innovation ability of universities. The current empirical evidence Research is less involved. Second, from the perspective of research objects, the existing literature mostly uses a single country as the research unit, and there are relatively few studies based on international comparisons, and the reference significance for the country's overall strategic decisionmaking is relatively limited. Third, the existing research mostly uses a single model for analysis, which seldom highlights the particularity and focus of the various input elements of university innovation at different stages of economic development. This article is an attempt to respond to these questions.

\section{Theoretical framework and research methods}

Based on the existing relevant theories and empirical research, this article has conducted a brief mechanism analysis of the relationship between university innovation ability and national economic growth shown in [Figure 1]. 


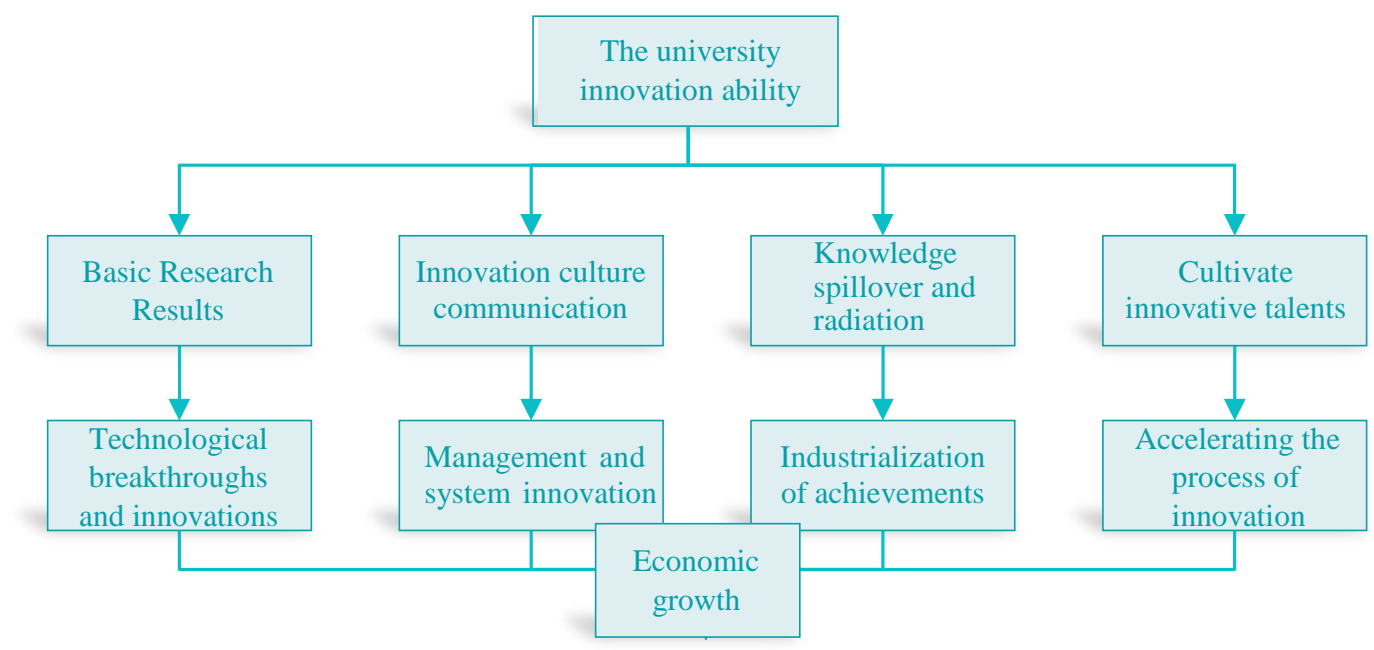

Figure 1. The internal mechanism of university innovation ability and economic growth

First of all, although the scientific research systems of various countries are different, research universities have a dominant position in a country's basic research and play an irreplaceable role in national knowledge innovation and technological innovation. As we all know, basic research in the United States is mainly conducted in universities. The effect of university innovation ability on economic growth is first reflected in basic research and knowledge creation. Basic research explores the objective laws of the world and expands the boundaries of human perception of the universe and itself. It is a prerequisite for technological leadership and a source of subversive and leap-forward innovation. Without the Maxwell equations of electromagnetic theory, modern power technology and electronic technology will not be developed. Without the Schrödinger equation of quantum mechanics, there would be no large-scale integrated circuits, the invention of various semiconductor devices, and a new generation of information technology and industrial revolutions. Without the major achievements of a series of basic research in the 20th century, there would not be today's rapid progress in science and technology and the rapid development of the knowledge economy. It can be said that in the past 100 years, the rapid technological progress and product updates of mankind are derived from the accumulation and wide application of basic research results, and universities are important bases for basic research.

Secondly, as a center of cultural development, universities are the nerves most sensitive to new ideas and new things in the social organism. In the process of scientific research and talent training, universities encourage independence, critical and creative thinking, which is conducive to creating an atmosphere of innovation, disseminating innovation culture, promoting people's concept renewal, and forming innovative thinking and innovative spirit. This is not only conducive to technological innovation but also conducive to promoting organizational innovation, management innovation, and system innovation. This is a significant difference between universities and other innovative entities. The form in which universities play this function is multi-level and multi-faceted: academic and technological activities, teaching method reforms, cultural and artistic propaganda, encouragement of 
innovation and entrepreneurship, and support for career development are all effective ways for universities to spread innovative culture inside and outside the campus.

Third, modern universities are not a closed system in theory and practice. Universities have extensive social connections, as well as numerous knowledge innovation and technological innovation platforms. They are key nodes in the flow of various types of knowledge and have significant knowledge spill over effects. Therefore, it plays an important role in promoting the agglomeration of innovative elements and enhancing the vitality of social innovation. On the one hand, this is conducive to strengthening the relationship between universities and society and enterprises, and realizing the industrialization of their scientific research results; on the other hand, it enables related enterprises and social organizations in the region to obtain university-produced products to a greater extent and at lower costs. All kinds of knowledge improve the knowledge accumulation and innovation level of enterprises and promote the optimization of industrial structure and high-quality development. In the benign interaction between the two, the enterprise will also feedback the innovation activities and discipline development of the university using scientific research funds and personnel support. The interaction between Stanford University and Silicon Valley is a typical case in this regard. This university, which has been rated as the "World's Most Innovative University" for many years, pays particular attention to technological innovation and the industrialization of its achievements. Thanks to the cooperation and interaction with research universities such as Stanford University and the University of California, Berkeley, the desolate valley of Silicon Valley has become one of the centers of the development of high-tech industries in the United States, effectively promoting economic growth in the region. According to statistics in 2011, there are about 40,000 companies that can trace their roots to Stanford University. If the output value of these companies is added up, it is equivalent to the tenth largest economy in the world, and Stanford University has become the university that receives the most corporate donations each year. one.

Finally, universities have an irreplaceable social mission in the selection, training, and reserve of innovative talents. The innovative talents they shape are the prerequisite for continuous social innovation, and are the continuous driving force of conceptual innovation, technological innovation, organizational innovation, management innovation, and institutional innovation. . As an important base for the production of innovative human capital, universities play a fundamental, leading and overall role in accelerating the innovation process in an all- round way and promoting sustained economic growth. Next, this article will empirically test the relationship between university innovation capabilities and national economic growth. Furthermore, this article will examine the importance and focus of the relevant elements of university innovation at different stages of economic development.

\subsection{Measurement model}

National economic growth is an explained variable, and this article uses unit labour output as its proxy variable. The unit labour output examines the ratio of the labour output created by a country to its corresponding labour consumption in a certain period. It is the comprehensive performance of the production technology level, the management level, the technical proficiency, and the labour enthusiasm of employees. The increase in unit labour output is the result of scientific and technological progress and the increase in investment in intangible assets such as innovation activities, education, and training. It is a manifestation of long-term economic growth and therefore is a symbolic economic indicator that measures a country's economic growth, competitiveness, and standard of living. 
It is worth noting that the traditional indicators of economic growth are per capita GDP and economic growth rate. Compared with per capita GDP, unit labour output excludes the effect of non-labourers in the country's total population, and can better characterize the actual efficiency of production. The economic growth rate is more limited by the country's economic base in the previous year. If the per capita GDP of a country in the previous year was US\$200 and the growth rate was $10 \%$, the actual growth was only US\$20; and if the per capita GDP of a country was US\$50,000 and the growth rate was $1 \%$, the actual growth would be US\$500.

The core explanatory variable that this article focuses on is university innovation ability. As mentioned above, the measurement of university innovation ability in existing empirical research mainly focuses on four dimensions: the macro-management system of university innovation, university innovation investment, university innovation activities, and university innovation achievements. This article examines the innovation capabilities of universities in various countries from the two dimensions of university innovation management system and university innovation investment, that is, analyzes the key elements of the formation of university innovation capabilities. The choice of this evaluation index is mainly based on two reasons: one is to help make the research results have more direct enlightenment significance to management practice; the other is to consider the comparability and availability of the data itself. The innovation activities of universities, such as international scientific and technological exchanges, scientific and technological services, and application of results, lack a unified statistical calibre in the world; while the innovation achievements of universities are mostly based on the output of papers and patents, but the same number of papers and patents, The quality and contribution to economic growth are often very different, and it is difficult to achieve accurate search for patent data of universities in various countries.

In terms of university innovation investment, existing research mainly focuses on $R \& D$ expenditure and R\&D personnel investment. This article uses two variables to express the percentage of university $R \& D$ expenditure in GDP and the number of university $R \& D$ personnel per million of the country's population. As far as the university's innovative management system is concerned, this article expresses the percentage of public higher education expenditures in various countries to the total expenditures of higher education. This indicator is a dual manifestation of the government's emphasis on higher education and the intensity of management and is closely related to the innovation performance of universities [10].

According to commonly used econometric models, economic growth is not only affected by the input of capital, labour, and comprehensive technical level but also closely related to the average quality of a country's labourers and industrial structure. This article controls these factors in the empirical analysis. The regression model is as formula (1):

$$
\begin{aligned}
& \text { LnOutput }_{\text {it }}=\alpha+\beta_{1} \text { HER } \backslash \& D_{\mathrm{tt}}+\beta_{2}\left(\text { Personnel }_{\mathrm{it}}\right)+\beta_{3} \text { Public }_{\mathrm{it}} \\
& +\beta_{4}\left(\text { Capital }_{i t}\right)+\beta_{5} L_{n}\left(\text { Labour }_{i t}\right)+\beta_{6} \text { Patent }_{\text {it }} \\
& +\beta_{7} E d u_{t}+\beta_{8} \text { Industry }_{i t}+\text { Country }_{i}+\text { Year }_{t}+\varepsilon_{t t}
\end{aligned}
$$

Among them, i represent the country, $t$ represents the year, Output is the unit labour output (constant price in 2010), HER\&D represents the percentage of University R \& D expenditure in GDP in various countries. Personnel are the number of university R\&D personnel per million people in each country. The public is the percentage of national public higher education expenditures in total higher education expenditures. Capital is the amount of capital formation per capita (constant price in 2010). Labour is the per capita labour force. A patent is the number of Triadic patent families owned by each country. Edu is the number of years of 
education per capita. The industry is the percentage of the added value of the service industry to GDP. $\varepsilon$ it is the random error term. $\beta \mathrm{j}$ is the estimated coefficient of each variable. In addition, to eliminate the influence of non-observed individual and time effects (Country and Year in the model) in the data, this paper uses a two-way fixed-effects model for regression.

It is worth noting that tripartite patents are an important innovation index established by the OECD, referring to patents that have been applied for at the same time at the European Patent Office, the Japanese Patent Office, and the US Patent and Trademark Office. There are many related indexes of patents. This article uses the number of tripartite patents as the proxy variable of the technical level of each country. This will help eliminate the influence of factors such as application procedures, geographic location, and domestic advantages among different patent offices, and increase the comparability of patent indexes in various countries. At the same time, because the tripartite patent application requires additional costs and time, it is more convincing in terms of patent quality. In addition, considering that many scholars in the theoretical field have pointed out that the relationship between R\&D intensity and economic output is not a simple linear relationship, the underlying reason is that excessive R\&D investment may squeeze other public expenditures or investment in other innovation entities. Therefore, drawing on the research conclusions of Hartmann and others, this article assumes that the marginal efficiency of $R \& D$ expenditures on economic output decreases [11][12][13], and adds the quadratic term of the variable university $R \& D$ expenditures.

To more accurately describe the relationship between university innovation ability and unit labour output, this article further uses the quintile regression model method proposed by Roger Koenker and Gilbert Bassett to distinguish between conditional distribution The relationship between the variables of the university's innovation ability, and the country's economic growth in different locations.

The unit labour output data in this article comes from the International Labor Organization. The total capital formation (2010 constant US dollars), labour force (total), service industry value-added, per capita education years data come from the World Bank database, university research and development funding, university research and development The number of personnel and patent data come from the open database of OECD countries. This paper matched the variable data of various countries and years, and finally constructed unbalanced panel data for 11 years in 33 countries on five continents.

\section{Empirical analysis}

\subsection{Stationarity test and descriptive statistics}

The data used includes both sample cross-sectional features and time-series features. To make the analysis results more accurate and reliable, the stationarity of the data is first tested. Since the data used in this article is unbalanced panel data, the IPS test, Fisher-ADF test, and Fisher-PP test are used to analyze the 9 variables in the model, including the unit labour output and the proportion of university R\&D expenditures, and their first-order differences. The results of the unit root test show that the original sequence of variables in the model is non-stationary, and the first-order differences of all variables pass the stationarity test at a significance level of $1 \%$. Since all variables are first-order single-integration, a co-integration test can be performed to verify whether the linear combination of each variable has a stable equilibrium relationship. The results of the Pedroni co-integration test show that the statistics reject the null hypothesis that there is no co-integration relationship between these variables 
at a significance level of $1 \%$, which indicates that there is a long-term stable relationship between the variables. The data is subjected to regression analysis.

Table 1. Descriptive statistics of each variable

\begin{tabular}{|c|c|c|c|c|}
\hline Variable & Minimum & Maximum & Mean & $\begin{array}{l}\text { Standard } \\
\text { Deviation }\end{array}$ \\
\hline \multicolumn{5}{|c|}{ The dependent variable } \\
\hline Unit Labour output (USD) & 17407.87 & 236561.6 & 75024.5 & 41349.55 \\
\hline \multicolumn{5}{|c|}{ Core independent variable } \\
\hline The proportion of university $r \& d$ expenditure & 0.06 & 1.01 & 0.44 & 0.21 \\
\hline Number of University R\&D Personnel (per million) & 167.27 & 3750.42 & 1740.68 & 755.45 \\
\hline $\begin{array}{l}\text { The proportion of public higher education } \\
\text { expenditure in total expenditure }\end{array}$ & 14.42 & 97.61 & 72.17 & 17.7 \\
\hline \multicolumn{5}{|c|}{ Control variables } \\
\hline Number of tripartite patents (thousands) & 0.0002 & 19.2955 & 1.1642 & 3.5559 \\
\hline Per capita years of education (years) & 6.8 & 14.1 & 11.402 & 1.4564 \\
\hline Services (value-added) as a share of GDP (\%) & 48.61 & 78.98 & 62.2 & 5.83 \\
\hline Per capita labor force & 0.3581 & 0.6148 & 0.4946 & 0.0419 \\
\hline Total capital formation per capita (USD) & 1480.07 & 25696.28 & 7748.01 & 4970.03 \\
\hline
\end{tabular}

\subsection{Two-way fixed effects regression results}

[Table 2] presents the regression results of the two-way fixed effects model. Model 2 adds the three variables of university innovation ability based on Model 1, the $\mathrm{R}^{\wedge} 2$ in the model increases from 0.6744 to 0.7211 , which explains $72.11 \%$ of the difference in unit labour output. The three variables that measure the innovation ability of universities all have a significant positive impact on unit labour output: university R\&D expenditure and R\&D personnel density are significant at the $1 \%$ significance level, and the government's financial support for higher education is at $10 \%$. The significance level of $\%$ is significant. The quadratic coefficient of university $R \& D$ expenditure is negative, and the first coefficient is positive, indicating that the relationship between university $R \& D$ expenditure and economic growth is an inverted U-shaped relationship, which reaches a peak when university $R \& D$ expenditure accounts for $0.5027 \%$ of GDP (1); In terms of the density of R\&D personnel, for every one million population, university $\mathrm{R} \& \mathrm{D}$ personnel increase by $1 \%$, and unit labour output will increase by $0.0647 \%$. At the same time, the results of the two models also show that after adding the variables of university innovation capabilities, the regression coefficients of tripartite patents, per capita years of education, and capita capital formation are all reduced, indicating that part of the effects of the three can be affected by the innovation capabilities of universities.

Table 2. Influencing factors of unit labor output

\begin{tabular}{|c|c|c|}
\hline Variable & Model 1 & Model 2 \\
\hline The proportion of university R\&D expenditure & & $0.4637^{* * *}(0.1202)$ \\
\hline The square of a university's r\&d budget & & $-0.4612^{* * *}(01005)$ \\
\hline Number of university researchers per million population & & $0.0647^{* * *}(0.0218)$ \\
\hline Share of public higher education spending & & $0.1041^{*}(0.0578)$ \\
\hline Tripartite patents & $0.0390^{* * *}(0.0114)$ & $0.0356^{* * *}(-0.0106)$ \\
\hline Years of education per capita & $0.0225^{* *}(0.0087)$ & $0.0166^{*}(-0.0084)$ \\
\hline
\end{tabular}




\begin{tabular}{|c|c|c|}
\hline Service sector share & $-0.3119(0.2035)$ & $0.3759 *(-0.1973)$ \\
\hline Per capita labor force & $-0.0706(0.1553)$ & $-0.1654(-0.1573)$ \\
\hline Total capital formation per capita & $0.1547 * * *(0.1546)$ & $0.1421 * * *(0.0201)$ \\
\hline Individual fixation effect & YES & YES \\
\hline Time fixed effect & YES & YES \\
\hline Intercept item & 9.4357 & 8.9528 \\
\hline Sample size & 257 & 257 \\
\hline R2 & 0.6744 & 0.7211 \\
\hline
\end{tabular}

\subsection{Quantile regression results}

Table 3 presents the results of the quantile regression model, and its estimated coefficient represents the marginal effect of the independent variable on the dependent variable at a specific quantile. With the improvement of quantile points, the effects of the three variables of university innovation ability on unit labor output have different trends in [Figure 2]. The university's R\&D expenditure has a positive predictive effect in the first 25 quantiles, and the coefficient after the 50 quantile turns into a negative value. In contrast, the regression coefficient of university $R \& D$ personnel density has gradually increased as a whole, and is at a significant level after the 25th quantile, reaching the highest value at the 90th quantile, indicating that it is in the middle and high-level group of unit labor output. The role of university $R \& D$ personnel density in promoting economic growth continues to increase. In addition, the coefficient of the proportion of public higher education expenditure first decreased and then increased, and all except the 50th quantile reached a significant level. The higher the proportion of public funding, it means that the source of funding for the university is relatively single, and it is usually accompanied by a stronger government leading role. The U-shaped trend of this index coefficient means that in the middle and low-level economic development groups of the sample countries, increasing government intervention will not be conducive to economic growth. Therefore, universities should improve their funding capabilities to promote the relationship between universities and society, universities and enterprises. The connection between the two can enhance the innovation vitality of the university. However, in the middle and high level of economic development, the government should provide adequate supply and play a guiding role due to the high risk and unpredictability of innovative activities.

Table 3. Quantile regression results of unit labor output

\begin{tabular}{|c|c|c|c|c|c|}
\hline Variable & 10 digits & 25 digits & 50 digits & 75 digits & 90 digits \\
\hline $\begin{array}{c}\text { Proportion of university R\&D } \\
\text { expenditure }\end{array}$ & $\begin{array}{c}0.0402 \\
(0.0598) \\
\end{array}$ & $\begin{array}{c}0.1850 * * * \\
(0.0687) \\
\end{array}$ & $\begin{array}{l}-0.0392 \\
(0.0519) \\
\end{array}$ & $\begin{array}{l}-0.0686 \\
(0.0937) \\
\end{array}$ & $\begin{array}{l}-0.267 \\
(0.1470) \\
\end{array}$ \\
\hline $\begin{array}{l}\text { Number of university researchers } \\
\text { per million population }\end{array}$ & $\begin{array}{l}-0.0197 \\
(0.0341) \\
\end{array}$ & $\begin{array}{l}0.0581^{* *} \\
(0.0267) \\
\end{array}$ & $\begin{array}{l}0.116 * * * \\
(0.0339) \\
\end{array}$ & $\begin{array}{l}0.0964 * \\
(0.0572) \\
\end{array}$ & $\begin{array}{l}0.149 * * \\
(0.0709) \\
\end{array}$ \\
\hline $\begin{array}{c}\text { Share of public higher education } \\
\text { spending }\end{array}$ & $\begin{array}{c}0.3808 * * * \\
(0.0755)\end{array}$ & $\begin{array}{l}0.2250 * * \\
(0.1030)\end{array}$ & $\begin{array}{c}0.0679 \\
(0.1150) \\
\end{array}$ & $\begin{array}{l}0.2680 * * \\
(0.1080) \\
\end{array}$ & $\begin{array}{c}0.291^{*} \\
(0.1650) \\
\end{array}$ \\
\hline Tripartite patents & $\begin{array}{c}0.005 \\
(0.0027) \\
\end{array}$ & $\begin{array}{c}0.0021 \\
(0.0033) \\
\end{array}$ & $\begin{array}{l}-0.007 \\
(0.0035) \\
\end{array}$ & $\begin{array}{l}-0.0047 \\
(0.0025) \\
\end{array}$ & $\begin{array}{c}-0.0076^{*} \\
(0.0045) \\
\end{array}$ \\
\hline Years of education per capita & $\begin{array}{c}0.0214 \\
(0.0157) \\
\end{array}$ & $\begin{array}{l}0.0168^{*} \\
(0.0091) \\
\end{array}$ & $\begin{array}{l}0.0205^{*} \\
(0.0112) \\
\end{array}$ & $\begin{array}{c}0.0081 \\
(0.0132) \\
\end{array}$ & $\begin{array}{c}0.0011 \\
(0.0153)\end{array}$ \\
\hline Service sector share & $\begin{array}{l}1.4221 * * * \\
(0.1614)\end{array}$ & $\begin{array}{c}1.5994 * * * \\
(0.2708)\end{array}$ & $\begin{array}{l}1.5291 * * * \\
(0.1987)\end{array}$ & $\begin{array}{c}1.7455 * * * \\
(0.3283)\end{array}$ & $\begin{array}{c}1.9266 * * * \\
(0.3756)\end{array}$ \\
\hline Per capita labor force & $\begin{array}{l}-1.0941 * * * \\
(0.1911) \\
\end{array}$ & $\begin{array}{c}-1.0613 * * * \\
(0.1390) \\
\end{array}$ & $\begin{array}{c}-1.1393 \\
* * *(0.1800)\end{array}$ & $\begin{array}{c}-1.0256 * * * \\
(0.2272) \\
\end{array}$ & $\begin{array}{c}1.1721 * * * \\
(-0.2501) \\
\end{array}$ \\
\hline Total capital formation per capita & $\begin{array}{c}0.8941 * * * \\
(0.0278) \\
\end{array}$ & $\begin{array}{c}0.7891 * * * \\
(0.0379) \\
\end{array}$ & $\begin{array}{c}0.8207 \\
* * *(0.0261) \\
\end{array}$ & $\begin{array}{c}0.7411 \text { **** } \\
(0.0325) \\
\end{array}$ & $\begin{array}{c}0.7378 * * * \\
(0.0389) \\
\end{array}$ \\
\hline Intercept item & 1.0143 & 1.4559 & 1.0067 & 1.9018 & 1.587 \\
\hline
\end{tabular}


The Relationship between University Innovation Ability and National Economic Growth based on Multinational Empirical Analysis

\begin{tabular}{|c|c|c|c|c|c|}
\hline Sample size & 257 & 257 & 257 & 257 & 257 \\
\hline R2 & 0.7579 & 0.7901 & 0.7785 & 0.7149 & 0.7135 \\
\hline
\end{tabular}
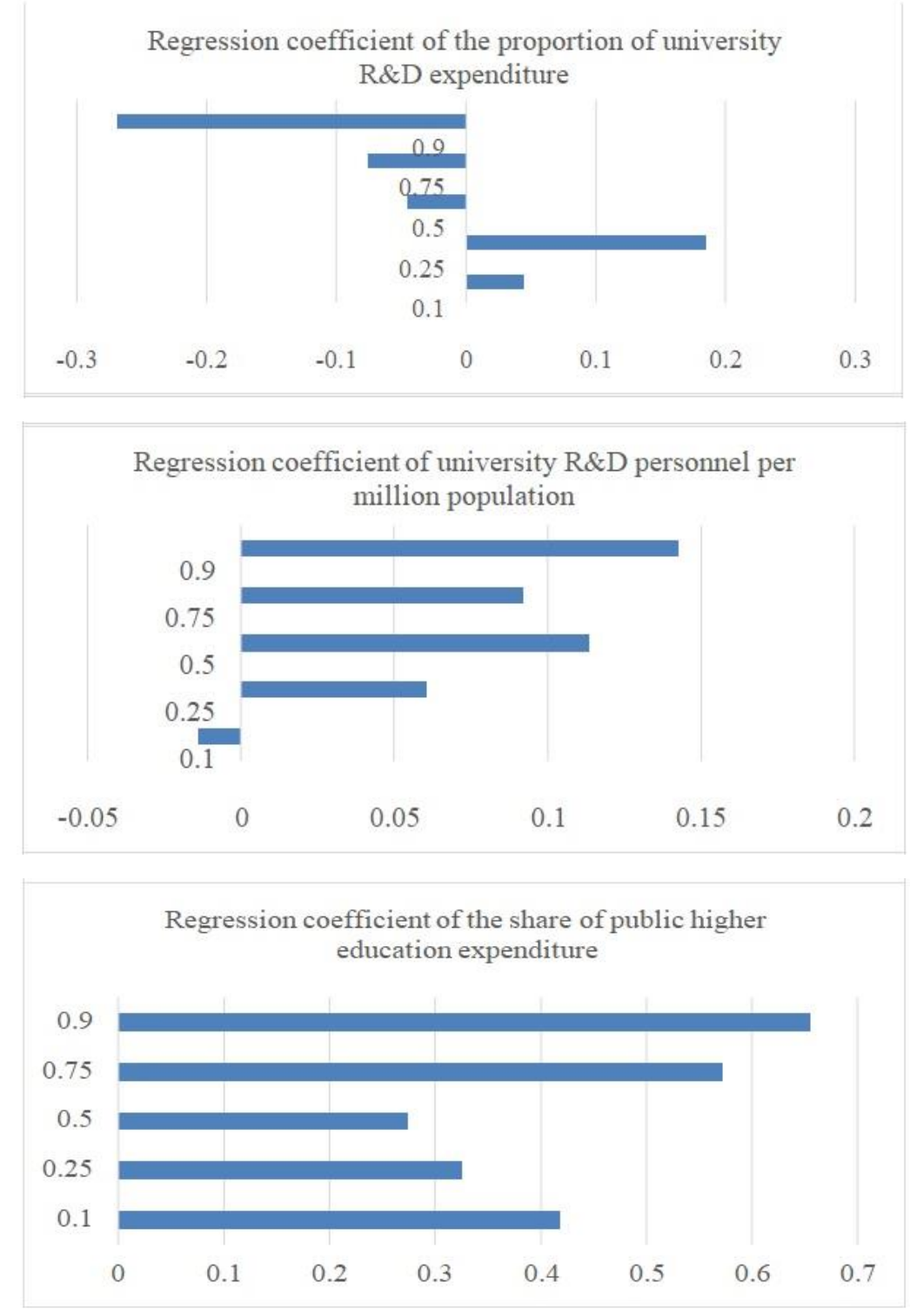

Figure 2. The change of the quantile regression coefficients of various factors of university innovation ability to unit labor output

\section{Conclusion}

In recent years, the issue of university innovation ability has attracted much attention. This paper examines the relationship between university innovation ability and unit labor output from three aspects: university $R \& D$ investment, university $R \& D$ personnel density, and government financial support for higher education. The main findings are summarized as follows.

First, after controlling factors such as capital, labor, technological progress, per capita education years, and industrial structure, the enhancement of university innovation 
capabilities will help increase unit labor output and contribute to long-term economic growth. This is consistent with the theoretical assumptions and the conclusions of most previous studies. It shows that improving the innovation ability of universities plays a decisive role in achieving high-quality development. For a long time, the main functions of universities have been positioned in personnel training and academic research, and their status in the entire national innovation system still needs to be further improved. In the process of economic growth model transformation, it is important to enhance the understanding of the strategic position of university innovation ability and focus on the leap from quantity to quality.

Second, in different stages of economic development, how university innovation works is different. In different positions of the conditional distribution, the role of university R\&D investment, R\&D personnel investment, and the degree of government financial support for higher education present different trends. Specifically, the quantile coefficient of university $R \& D$ expenditures first increased and then decreased; the contribution coefficient of R\&D personnel density to the increase in unit labor output continued to increase; the degree of government financial support for higher education and economic growth showed a U Type relationship.

Third, in the long run, the government needs to maintain sufficient financial support. The enlightenment that the government's financial support for higher education brings to the Ushaped relationship between economic growth lies in the following: On the one hand, increasing the sources of funding for running schools through multiple channels will help universities and society to form a more effective interaction mechanism and improve Innovation vitality and motivation of own university. On the other hand, because innovative activities are highly risky, unpredictable, and long-term. Innovative activities implemented by universities have higher sunk costs than enterprises, and both scientific research and talent training require continuous high investment. From a breakthrough in basic research to commercialization, it usually takes 20 to 30 years. For example, the research of artificial intelligence technology in the United States began in the 1970s, and it was not until 1997 that a personal computer capable of successfully recognizing persistent speech was developed. The basic research on three-dimensional images originated in the 1960s, and it was not until the 1990s that consumer products were formed. The formation of the individual's innovative spirit and innovative ability cannot be achieved overnight, and the entire education process and cultivation mechanism need to be integrated. Therefore, when the national unit labor output reaches a relatively high level, the full play of the role of university innovation depends more on the government's strategic vision and institutional support. Fourth, any innovation subject cannot act in isolation but needs to adapt and collaborate. The results of this article show that the degree of correlation between university $R \& D$ investment and economic growth first rises and then declines. This means that attention should be paid to avoid blindness in investment at all stages of economic development and to maintain various innovation-related entities (universities, scientific research, etc.). The balanced investment of institutes, enterprises, non-profit organizations) is conducive to the maximization of the utilization rate of $\mathrm{R} \& \mathrm{D}$ resources and the maximization of output. In the short term, there may be an imbalance between the input and innovation output of different innovation entities, but there is a synergy relationship in the long run. In terms of international experience, developed countries usually pay attention to the differentiated division of labor and positioning between different innovation entities to achieve collaborative innovation. Taking Germany as an example, research universities take basic research as their main function, other research institutions such as Max Planck Institute focus on applied basic research, and FraunhoferGesellschaft conducts extensive applied research. American research universities undertake 
more than $50 \%$ of basic research tasks and attach great importance to exchanges and cooperation with national laboratories to promote high-tech transfer. In addition, based on maintaining the rational allocation of innovation resources and the appropriate scale of each subject, the efficiency of innovation resources should be improved through concept innovation, system innovation, and management innovation, and a sustainable development mechanism should be constructed to promote long-term economic growth.

\section{References}

[1] C. Freeman, "The national system of innovation in historical perspective," Cambridge Journal of Economics, vol.19, no.1, pp.5-24

[2] R. Nelson, "National innovation systems: A comparative analysis," New York: Oxford University Press

[3] H. Ezkowitz, "The three-helix innovation model: selected works of Henry Ezkowitz,"

[4] H. Chesbrough, "Open innovation: The new imperative for creating and profiting from technology," Boston: Harvard Business School Press, (2003)

[5] G. Eliezer, "Industry -university technology cooperation-a theory of inter-organizational relationships," Technology Analysis \& Strategic Management, vol.7, no.2, pp.217-229

[6] M. Gibbons et al., "New models of knowledge production: the dynamics of contemporary social science and research,"

[7] R. Geiger, "The paradox between universities and the market,"

[8] F. Martin, "The economic impact of Canadian university R\&D," Research Policy, vol.27, no.7, pp.677-687

[9] D. Woodward, O. Figueiredo, and P. Guimares, "Beyond the Silicon Valley: University R\&D and hightechnology location," Journal of Urban Economics, vol.60, no.1, pp.15-32. (2006)

[10] P. Aghion, M. Dewatripont, C. Hoxby, A. Mas-Colell, and M. Sapir, "The governance and performance of universities: Evidence from Europe and the US. Economic Policy," vol.25, no.61, pp.7-59, (2010)

[11] G. C. Hartmann, M. B. Myers, and R. S. Rosenbloom, "Planning your firm's R\&D investment," ResearchTechnology Management, vol.49, no.2, pp.25-36, (2006)

[12] C. H. Wang, "Clarifying the effects of R\&D on performance: Evidence from the high technology industries," Asia Pacific Management Review, vol.16, no.1, pp.51-64, (2011)

[13] M. L. Yeh, H. P. Chu, P. J. Sher, and Y. C. Chiu, "R \&D intensity, firm performance and the identification of the threshold: Fresh evidence from the panel threshold regression model?" Applied Economics, vol.42, no.3, pp.389-401, (2010) 